This item was submitted to Loughborough's Research Repository by the author.

Items in Figshare are protected by copyright, with all rights reserved, unless otherwise indicated.

\title{
Rethinking construction expertise with posthumanism
}

PLEASE CITE THE PUBLISHED VERSION

http://dx.doi.org/10.1080/01446193.2015.1122201

PUBLISHER

(c) Taylor and Francis

VERSION

AM (Accepted Manuscript)

PUBLISHER STATEMENT

This work is made available according to the conditions of the Creative Commons Attribution-NonCommercialNoDerivatives 4.0 International (CC BY-NC-ND 4.0) licence. Full details of this licence are available at: https://creativecommons.org/licenses/by-nc-nd/4.0/

\section{LICENCE}

CC BY-NC-ND 4.0

\section{REPOSITORY RECORD}

Sage, Daniel J.. 2019. "Rethinking Construction Expertise with Posthumanism". figshare. https://hdl.handle.net/2134/19808. 


\section{Rethinking construction expertise with posthumanism}

\section{Abstract}

Expertise is commonly understood to be a distinct, even defining, aspect of being human - an attribute related to our efficacies to come to know and influence the, mostly nonhuman, world around us. In construction, expertise is commonly defined as the acquisition of skill and knowledge related to new technical processes, organizational routines, health and safety codes, even cultural norms. Despite the development of rule-following 'expert systems' in construction and beyond, the proposal that nonhuman technologies and artefacts can share our expertise is thus to be regarded with doubt: humans are human because of their lived expertise to undertake tasks faster and better than machines and other nonhumans. Increasingly, however, this anthropocentric view of expertise can be challenged by a 'posthuman turn' that is gathering pace across the social sciences and humanities. In this paper I evaluate, via the work of four seminal posthuman thinkers, the distinct, and varied, contribution that posthumanism might make to how we understand notions of construction expertise. In so doing I draw upon fictional examples of construction practices to illustrate the challenge and theoretical and practical opportunities in rethinking construction expertise via posthumanism.

\section{Introduction}


Theories of expertise tend to define it through a particularly human notion of agency, wherein a more or less self-governing human actor is involved in the acquisition of skills, knowledge and capabilities, increasing their efficacy to shape an external reality. (Eyal, 2013) Within psychology, well-cited theories of expertise, such as those developed by Karl Anders Ericcson and colleagues (Ericcson, et al. 1993; Ericcson and Lehman, 1996; Ericcson et al 2007), have sought to understand how people acquire expertise in new skills, knowledge and capabilities, through deliberate, and sustained practise, fostering psychological and physiological changes. Sociologists have similarly defined expertise through human notions of agency to examine the socialized capacities that enable human actors to define, delineate and control the legitimacy and value of their skills and knowledge, especially through professional institutions and discourses (Evetts, 2006; Friedson, 2001; Knapp, 1999; Larson, 1977). And again, within these sociological studies the primary object of analysis is people, their agency to modify a world, populated by active humans, and more passive nonhumans, through the acquisition of certain practices, knowledge, institutions and languages. These human-orientated definitions of expertise have, in turn, influenced organizational analyses. Psychological studies have revealed the importance of organizational variables, such as performance feedback and environmental stability, to understand the propensity of human actors to develop certain knowledge with measurable performance outcomes (Shanteau, 1992). Sociological approaches have examined the politics of professionalization, to show how class-based interests and agendas, are more or less successfully defined and secured through attributions of skills and knowledge across different occupational, organizational and societal contexts (Reed, 1996; Zald and Lounsbury, 2010), not least those of construction (Styhre, 2011). 
Notwithstanding the predominant focus upon humans in definitions on experts and expertise within psychology and sociology, on-going attempts have been made to construct legitimate conceptualizations of nonhuman expertise, especially within computer science. Initiated by the seminal work of Edward Feigenbaum, 'expert systems’ have been developed: rule-based computer programmes designed to solve problems more effectively and efficiently than humans (Feigenbaum, 1992). Expert systems have been proposed across all manner of domains, from medicine (Adler et al. 2014) to finance (Leigh et al. 2002), and construction (Alkass et al. 1996; Okoroh and Torrance, 1999). However, as the philosophers Dreyfus and Dreyfus (2005) explain, 'although computers are faster and more accurate than people in applying rules, master-level performance has remained out of reach' (p781). For Dreyfus and Dreyfus (2005) such rule-based ‘expert systems’ cannot achieve real expertise as expertise always requires a movement away from abstracted rules to real world complexities. For instance, a novice DIY enthusiast is entirely reliant upon a set of abstract instructions to hesitantly and laboriously construct a fragile and untidy brick wall. By contrast, a master bricklayer subtly and appropriately reacts to differences in the texture, weight and composition of the bricks, the temperature and viscosity of the mortar, and the gradient of the land, to quickly construct a strong and attractive wall. Hence for Dreyfus and Dreyfus's (2005), although a robotic bricklayer linked to an expert rule-based system might be better than a beginner in following rules quickly and may make fewer crude mistakes, it could never possess the expertise of a human expert to adapt to real world contexts. As with much sociological and psychological theorizing on expertise, Dreyfus and Dreyfus's (2005) influential philosophical refutation of rule-based expert systems reaffirms the notion that expertise is distinctly human. It would seem intuitive to agree with their sentiments. After all, if a costly expert system is incapable of solving problems as effectively and efficiency as the human experts that informed its production (Dreyfus and Dreyfus, 2005), why, and indeed 
how, should we admit nonhumans into theories of expertise? In other words, in what sense should we recognize expertise as posthuman? In what follows I will examine these questions more fully and their implications for conceptualizing expertise in construction.

Notwithstanding their clear diversity, what unites the definitions and theories of expertise discussed above is their reliance upon a certain figure of human agency: a subject invested with certain skills and knowledge, more or less independently of a passive nonhuman setting and then acting upon that setting to accomplish a 'task better and faster' (Eyal, 2013: 869). Even adherents of expert systems, still tend to assume that abstracted human skills and knowledge are to be passively encoded into computer systems, independent of the nonhumans that make a difference to the efficacy of those human skills and knowledge (Dreyfus and Dreyfus, 2005). Recall in the brief example above how many nonhumans can make a difference to the skill and knowledge of the master bricklayer (texture, weight and composition of the bricks, the temperature and viscosity of the mortar, and the gradient of the land). Thus, if we focus upon encoding abstract human rules of expertise into a computer system, independent of this complex interplay of forces and actors, we tacitly affirm, rather than rework, a humanistic image of expertise. To contest this pervasive humanism we can turn to a body of 'posthuman' thinking that challenges the boundaries of what we commonly perceive as human action, thought and interaction, including practices often labelled as expertise. In setting out on this task here I am not proposing a search for the soul or mind of machines, or other nonhuman bodies, but rather, as per Latour and others, I would like to contend, simply far greater recognition that nonhumans often, though not always, make a difference to how we act or think, not least when we claim to do so as 'experts' (cf. Cooren et al. 2006). It is this more modest notion of agency as simply 'making a difference' (Latour, 2005: 71) to the flow of action (including thought), or, simply put, 'they can make things 
happen' (Bennett, 2010: 5), that frames this examination of posthuman thinking and its application to notions of expertise in construction and elsewhere. This is not to say that nonhumans determine the action either, rather it is a call to a more nuanced, subtle understanding of agency as a collective, distributed, interplay of different agencies that collectively make a difference because they are different (Bennett, 2010; Latour, 2005). Thus, in formulating this 'posthuman' account I reject the idea that human and nonhuman agencies are the same but I do contend that they should both be acknowledged in an analysis of collective agency, and thus expertise. This collective view of agency also contests the idea, given in most studies of expertise, that action, meaning and knowledge are always ultimately reducible or attributable to a human will, plan, intent or design. Rather, it is futile to try and trace agency, including thought and meaning, to a source of human intellect as it is always a collective process, involving multiple actors, human and nonhuman.

To unpack these ideas further I will discuss four 'posthuman' theorists - Donna Haraway, Karen Barad, Rosi Brandiotti and Bruno Latour. Each of these thinkers propose a particular way of thinking about what we might term the posthuman condition. While these theorists differ in their philosophical approaches, and indeed some might reject the label 'posthuman' (e.g. Haraway, 2008; Latour, 1993), they all help us question the human sovereignty over agency, thought and action, in ways that in turn help us in turn to rethink received conceptualizations of expertise in construction, whether those derived from psychology, computer science, or sociology.

In what follows I briefly outline how expertise has be thus far conceptualized in construction in humanistic terms and some of the limitations of these approaches. I then turn to four 
'posthuman' theorists: Haraway, Barad, Brandiotti and Latour. Given space constraints, for each theorist I will focus upon a single concept discussed in a single piece, or section, of their work. As such this paper is not intended to offer a thorough précis of the complexities, intricacies and dynamics of each theorist's thinking or poshuman thinking in general (see e.g. Herbrechter, 2013; Roden, 2015). Instead, the aim of the paper is to open up a consideration of the application of 'posthuman' approaches to inform studies of expertise in construction management research. The four theorists have been chosen in part due to the prominence of their intellectual contribution across social sciences, but also because of the different concepts they mobilize in their challenge to the conventional notions of human agency, and in turn the efficacy of humanistic notions of expertise. Yet, despite their differences, the thinkers discussed here do share some similar disciplinary ties, especially with the sociological analysis of science and technology, or Science and Technology Studies (STS). This is no accident, as it is in our entangled relations with modern technology, and their effect on our social relations, that our posthuman condition is perhaps most sharply being thrown into relief. Within each of the four discussion I begin by detailing the contribution of each of these theorists and locating them in the social sciences and humanities. I then proceed to explain the relevance of their thinking to conceptualizations of expertise, drawing upon short hypothetical examples of construction management. After discussing these theorists, I will by way of conclusion reflect more fully upon the contribution of thinking with posthumanism to understand construction expertise and suggest possible avenues for future research.

\section{Humanism and Construction Expertise}


There are remarkably few focussed studies of expertise within construction management, although understandings of expertise are implicit within wider bodies of research, notably those around knowledge management. A long-standing strand of work upon expertise in construction is that influenced by work upon expert systems. Alkass et al. (1996), for example, propose a delay analysis technique, drawing upon a computerized expert system, as a solution to minimize delays and thus costs in construction projects. Similar expert systems have been proposed in other areas, such as sub-contractor selection (Okroh and Torrance, 1999) and the selection of procurement systems (Chan et al. 2001). This strand of research promises to equip practitioners with computerized systems, based upon encoded abstract rules, to improve their decision-making. Just as with other expert systems research, these approaches are, despite their use of IT systems, tacitly humanistic, in that they are based upon encoded human abstractions of construction project work, independent of the complex dance of human and nonhuman agencies that occur on-site. This tendency, which is common to expert systems approaches (Dreyfus and Dreyfus, 2005), arguably explains their rather limited use in solving problems within construction projects.

Other research that addresses construction expertise is more explicitly influenced by sociological theories of expertise. Gluch and Räisänen (2009), for instance, draw upon interactionist social theories to show how the expertise of environment consultants is received within civil engineering projects. Nonhumans do feature in their account, but only as 'mediation tools' that are 'used to convey or appropriate a message' (p166) between humans actors. Nonhumans, such as computer intranet systems, are essentially passive in this account - mere 'tools' that faithfully transports our actions, whether well-considered or not. Thus, analytical attention is ultimately directed to the human actors making the decisions about which tools are appropriate to carry what form of expert knowledge in which organizational 
contexts. No explicit consideration is paid to how nonhuman technologies, like intranet systems, might actually be involved in shaping the meaning of the expert identities of certain practitioners such as the environmental officers. Nevertheless their analysis does offer an implicit consideration of how nonhumans can make a difference to construction practice, as Gluch and Räisänen (2009) explain how mediating tools help decouple construction projects from the permanent organizations espousing environmental expertise.

In a similar study to Gluch and Räisänen (2009), Dossick and Neff (2011) draw upon grounded theory to explain how BIM models shape the interactions among building design and construction professionals. Again, nonhumans feature quite strongly in their account but only as 'communication tools' (p85) that are more or less effective conduits for human intents and designs. By adopting our modest, collaborative, view of agency, we can see how within Dossick and Neff's (2011) study, nonhumans, such as computerized BIM models, do make a difference to the skills and knowledge of the practitioners discussed; specifically, they help engender problem identification but may inhibit problem solving. Nevertheless, the key actor in Dossick and Neff's (2011) analysis remains the self-governing human expert, capable of deciding amongst the appropriateness of a series of communication tools, not the nonhumans, whether BIM tools of pieces of paper, that may have already influenced, though not determined, this decision-making.

The role of nonhumans as mediators of expertise is also implicit in Boudeau's (2013) more recent ethnomethodological interpretation of an interaction between the expertise of a structural engineer and a landscape architect in a design meeting. Boudeau (2013) discusses how the human actors carve out their domains expertise, and the relations between them, with 
reference to the design of a roof garden on a hospital. Implicit within Bourdeau's (2013) study is an account of how the structural engineer can effectively only assume power over the landscape architect because the roof garden will make a difference to the structure of the building; in particular heavy plants will, albeit over time, interact with structural columns. However, Boudeau's (2013) analysis does not consider the agency of these nonhumans in the co-ordination of expertise; instead, following the tenets of ethnomethodology, she focuses her attention on the minutiae of linguistic interactions occurring between the two human actors in the meeting.

These diverse studies all evidence a humanistic orientation in how construction expertise is currently being defined, understood and analysed, whether influenced by approaches in computer science or social science. And yet notably, social science studies such as those describe above, have started to implicitly register the possibility for a more active role for nonhumans as mediators of human actions and thoughts, not least those related to expertise. This is not surprising: it is difficult to follow any social connection in empirical detail without registering the vitality of nonhumans (Bennett, 2010; Latour, 2005). What is now required alongside such empirical insights are theories capable of informing an analysis of how notions of expertise might be reworked by actors and agencies that are not exclusively human. Pursuing this agenda, I will now turn towards four concepts within writing from thinkers of what might be termed 'posthumanism' to elaborate upon some possibilities for rethinking notions of expertise in construction. Instead of grounding my discussion of these posthuman thinkers around a singular definition of expertise, whether from psychology, sociology or computer science, I instead develop four posthuman interventions into and around different aspects of extant conceptualizations of expertise and their possible application for construction research. This approach adopts a more relational, or 
performative, ontology, as shared by most 'posthuman' thinkers, wherein reality, such as construction expertise, is not a singular object out there waiting to be discovered, but rather is enacted, and, as such, can be multiple (Law, 2006). I will also repeat another caveat stated at the head of this paper: what follows is not intended to be an exhaustive account of posthumanism or the theorists discussed, but rather it is intended to specify some concepts that can help us rethink notions of the human, and in particular human agency, in construction expertise. Each concept will be introduced and then contextualized within notions of construction expertise.

\section{Thinking with posthumanism}

Haraway’s (1991) Cyborg

In 1985 Donna Haraway published an essay titled the A Cyborg Manifesto in the Socialist Review; this essay was later republished in her 1991 edited collection, Simians, Cyborgs and Women: The Reinvention of Nature. In this essay, Haraway (1991), a feminist scholar in STS, deploys the hybrid figure of a human/nonhuman cyborg as a metaphor to challenge the binary thinking in prevailing feminist thought where the human category of 'woman' was opposed to technoscience (Grusin, 2015b). Harway’s (1991) cyborg is mobilized to suggest a more relational ontology between humans and nonhumans, 'whereby each entity only is by virtue of and through its relationship to another' (Rae, 2014: 506). For Haraway (1991), this ontological claim is also political act, challenging what she viewed as masculinist assumptions of unity, reason, hierarchy, purity, progress, control, detachment and order, 
percolating around Western science, culture and politics. Such a disembodied, humanistic worldview, and its accompanying purist binaries of separation, are, Haraway (1991) suggests, to be challenged as they affirm masculinist desires to remove ourselves, and our 'more than human' bodies, from the world, helping justify attempts to define and control the lives of human and nonhuman 'Others', thus leading to 'the domination of women, people of color, nature, workers, animals - in short, domination of all constituted as others, whose tasks is to mirror the self' (Haraway, 1991: 177). This is why the political ends of Haraway’s (1991) cyborg figure are inseparable from more ontological questions of what it is to be human. In building this challenge to the boundaries of the 'human', Haraway's (1991) cyborg gathers together various ingredients: Darwin's theory of evolution; wearable consumer electronics; globalized capitalism; Star Wars missile defence; artificial intelligence, robotics, biotechnology, population control and genetic engineering. Across these domains the boundaries between humans, animals and machines are rendered unknowable in advance, and so subject to political debates. The proliferation of contemporary technology is a key vector here because 'It is not clear who makes and who is made in the relation between human and machine' (Haraway, 1991: 177); 'the machine is not an it to be animated, worshipped, and dominated. The machine is us, our processes, an aspect of our embodiment' (Haraway, 1991: 179; emphasis). Crucially, as Haraway (1991) explains, the cyborg requires a new form of expertise: 'the skilful task of reconstructing the boundaries of everyday life, in partial connection with others, in communication with all of our parts...it means both building and destroying machines, identities, categories, relationships, space stories’ (p181). Knowingly straddling the boundaries between social science reality and literary fiction, Haraway's (1991) essay is as poetic as it is precise. Above all, it encourages us to ask questions about the political consequences of defining what is and what is not 'human'. If, indeed, we know think and act with machines rather than upon them, our decisions, not least our 'expert' decisions, 
about whether, and how, to admit this 'posthuman' condition do appear distinctly political. For instance, a structural engineer may deploy her 'expertise' to differentiate herself from her drawings, computer software and models when those models reveal structural defects; yet in rectifying this fault she will admit those nonhumans into her capacity to think and act with 'expertise'. Here the politics of expertise is not only explainable in terms of the legitimizing action of professional bodies and class structures (Friedson, 2001; Knapp, 1999; Larson, 1977) the minutiae of linguistic rules (Boudeau's (2013), or the social interaction of human actors (Gluch and Räisänen (2009), Dossick and Neff (2011), but also the on-going boundary work around which human agency is differentiated from its Other (cf. Cooren et al. 2006). Haraway’s (1991) cyborg figure, and her later thinking (e.g. Haraway, 2008), has had a strong influence on posthuman thinking across the social sciences, both in terms of the commitment to relational ontologies (Grusin, 2015a) and empirical analyses of contemporary ‘cyborgisation’ (Rae, 2014). Unfortunately, owing in part to its metaphorical orientation, Haraway's (1991) cyborg figure does not help us discuss in great detail how this process of acting with technology (or other nonhumans) takes place, and indeed how it might connect with concepts related more explicitly to notions of expertise. To go further in this direction I will now turn towards the work of another posthuman thinker, one who, unlike Haraway (1991), does explicitly label her work as ‘posthuman’ - Karen Barad.

Barad's (2003) Posthumanist Performativity

Like Haraway, Barad is a feminist scholar working within the field of STS. In 2003 she published 'Posthumanist Performativity: Towards an Understanding of How Matter Comes to Matter' in Signs: The Journal of Women in Culture and Society. This paper has been cited across disciplines as diverse as medicine, social science, management studies, planetary 
science and neuroscience. In the paper Barad (2003) argues for a concept of 'posthuman performativity' to enable us to think through the active contribution of matter to the construction, or 'enactment', of material realities. This approach is contrasted to the then (and perhaps now) prevailing emphasis within the social sciences on explaining the social construction of material realities as the product of linguistic representations, whether via some form of scientific realism, or the poststructrualist ruminations of Judith Butler's performativity, or Michel Foucault's discursive practices. For Barad (2003: 803-811) all these accounts separate the world into words, pre-material subject and things, such that matter appears to play a passive role to the historical forces of largely linguistic discourses.

To enliven matter so that it is neither a transcendental given or human creation, Barad introduces her notion of posthuman performativity. Barad's (2003) concept of posthuman performativity is developed through her analysis of the Nobel-winning quantum physicist, Niels Bohr. Barad's (2003) thesis stems from Bohr's acknowledge of the epistemological importance of quantum mechanics, and in particular the crucial role of the scientific observer and their apparatus in understanding seemingly 'fixed' and 'external' quantum properties such as position and momentum. As Barad (2003) explains, Bohr's relational thinking does not merely challenge how we come to know the world as an external reality (epistemology) but also the nature of reality (ontology). This is because, for Barad (2003), objects and subjects are causally constructed, or performed, through these, and other, agential relations. Consider a construction example: a surveyor measuring the topology of a piece of land to evaluate its suitability for development. Barad's (2003) posthumanist performativity suggests that it is through this act of measurement, and the apparatus involved, such as theodolites, ground radar, maps, and soil sampling devices, that the development land and the surveyor come to matter in a meaningful way, and in the case of the latter, the surveyor develops her 
expertise. And thus, the development land and the surveyor with expertise, are emergent properties or in Barad's terminology, phenomena, caused by their interaction. If the theodolite, ground radar, maps and soil sampling devices did not exist, nor arguably would the expertise of the surveyor. To repeat the general argument around nonhuman agency and expertise set out earlier in this paper, Barad's (2003) posthumanist performativity does not imply that these nonhumans determine the meaning of the expertise of the surveyor, independent of her presence, but that these nonhumans do shape her expertise to an extent that this expertise is unknowable as such without their presence; and moreover that this amalgamation of complex relations may create new forms of expertise. As with Haraway (1991), Barad (2003) adopts a relational ontology, where subjects and objects are emergent properties of their relations, rather than relations being the emergent phenomena between a field of objects and subjects. What is more, Barad (2003) suggests that discursive meaning and matter are produced through such interwoven agential interactions wherein matters, including human bodies and indeed notions of expertise, come to materialize, in a meaningful way, or not: 'The point is not merely that there are important material factors in addition to discursive ones; rather, the issues is the conjoined material-discursive nature of constraints, conditions and practices' (p823). Viewed in this way, agency and meaning, including expertise, can never be the products of objects, such as expert systems (Okroh and Torrance, 1999), or subjects called experts (Boudeau, 2013). This is because for Barad (2003) these relata cannot pre-exist the agential relations through which they are enacted; rather, agency is this uncertain interaction, while objects and subjects, and localized and temporary notions of cause and effect, are its effects. This denial of a priori relata challenges sociological and psychological theories of expertise, wherein experts can pre-exist the everyday mechanisms through which their tasks and competence are measured, whether through their professional legitimacy (Friedson, 2001) or specialist cognitive capabilities (Ericcson et al 2007). 
Moreover, as discussed above, analyses of expertise in construction (e.g. Boudeau, 2013; Dossick and Neff, 2011; Gluch and Räisänen, 2009) still ascribe a priori reality to the human actors involved and their possession of specialized knowledge and skill, rather than consider how the socio-material interactions around these actors might actively produce these actors, their knowledge and skill.

Barad (2003) takes us beyond Haraway’s (1991) broad call to register what might be termed our posthuman, or nonhuman, condition to help us consider the important question of how we can start to think about ourselves, including our expertise, within this posthuman condition. However, in so doing Barad's (2003) posthumanist performativity becomes more detached from the political and ethical relevance of registering our posthuman condition. Within any consideration of expertise, questions of the legitimacy of experts and the ethics of professional knowledge are of paramount importance, not least in construction (Brown and Phua, 2011). A valuable bridge between the philosophy and politics of posthuman thinking can be found in the work of another feminist thinker, Rosi Bradiotti.

Braidiotti’s (2013) Posthuman Subject

Rosi Braidiotti (2013) unlike Haraway and Barad is a philosopher by training, not a philosophically orientated STS scholar. Given this, her writing, and influences, roam rather more widely across the humanities and social sciences, and indeed she has recently produced a book on the history of posthumanism which spans Western philosophy and social theory, encompassing the writing of Haraway and Barad. This title, The Posthuman (Braidiotti, 
2013), culminates in her explication of the ethics and politics of the posthuman condition, or subject, drawing especially on the writings of the French philosophers, Gilles Deleuze and Felxi Guattari.

Braidiotti's (2013) conclusionary piece in The Posthuman begins with a call to 'invent forms of ethical relations, norm and values worthy of the complexity of our times' (p186). Braidiotti is explicitly concerned throughout this text with the question of 'how can we stop the posthuman from becoming inhuman(e)' (p187). Thus her ethics is far from a call to curtail our relations with modern technology. Rather, Braidiotti (2013) fleshes out a distinctly 'posthuman' subject as an affirmative ethical virtue. This subject departs from the seemingly more morally relativist subject of poststructuralist thinkers such as Foucault. While this poststructuralist/postmodern subject can be captured by totalizing structures of power, notably linguistic signifiers of power/knowledge/discourse, Braidiotti's 'posthuman subject' cannot. Instead she proposes that posthuman subjects are produced through immanent, localized and material practices. To take another construction example: we might consider how we interact with a Building Information Model (BIM) to foster new possibilities for how we define ourselves and others. As we build a BIM model we enact differences between our professional responsibilities, knowledge and expertise and those of other parties within a project. Following Braidiotti we can view such model building as an ethical process of subject formation, wherein subjects deemed 'experts' are created in ways that can serve multiple ethical outcomes. On the one hand, such technologically mediated practices can enact new opportunities to discipline bodies and minds - for example, in the case of BIM, working selves, such as site managers, sub-contractor managers, planners design managers, can be produced through conformity to the knowledge and skills of distant others, such as structural engineers, clients and architects. On the other hand, such technologies might also 
create new possibilities for novel working selves and forms of expertise - the 'BIM hacker', 'BIM saboteur' or 'BIM refuser' - to emerge with more possibilities to resist such discipline through expertise. This hypothetical example dovetails to an extent with Dossick and Neff's (2011) empirical study of BIM. Specifically, Braidiotti’s (2013) thinking about the ethical possibilities of technology, connects with the observation that the formal capacity of BIM to encourage the development of, perhaps quite esoteric, expertise in identifying problems in the building process but not help solve them, may, rather counterintuitively, proliferate the requirement that construction expertise becomes simultaneously bound to skills in more informal, less computerized, even more democratic, forms of problem solving (Dossick and Neff's (2011). Thus Braidiotti (2013) does not deny the existence of structures of power, such as those of advanced capitalism and its technological products, these are always multiple and never monolithic, and always breeding multiple opportunities for experimenting with forms of creativity and resistance. These practices therein pose embodied, localized, ethical opportunities, through which we can expand our possibilities to build new communities which for Braidiotti must include nonhuman others.

Paraphrasing Deleuze and Guattari, Braidiotti (2013) proposes that this posthuman subjectivity, or condition, leads us to an ethics wherein our bodies are always being inserted, often within our will of recognition, into chains of relations with nonhumans, whose unfolding vitality, entails an ethics of immanent vitality: 'we simply do not know what our enfleshed minds and bodies, can actually do' (p190). This implies an affirmative, positive ethics that does not centre upon a protective ethos of human self-interest, and negativity towards evermore complex relations with technology, rather it unfolds through experiments in how why might define and sustains new communities, collectives and futures with others, human and nonhuman. Braidiotti (2013) concludes by reinventing Nietzsche’s maxim: 
'Human, all too posthuman, these extensions and enhancements of what bodies can do are here to stay. Are we going to be able to catch up with our posthuman selves, or shall we continue to linger in a theoretical and imaginative state of jet-lag in relation to our lived environment' (p197). Like Haraway, Braidotti challenges us to embrace the complexities of our relations with new technology, rather than retreat into, what she would no doubt term a mythical, distinctly human world of control, unity, detachment and indeed expertise. Braidotti's thinking therein diverges from most writings of expertise, across sociological and psychology, and in particular the humanism found in the work of Dreyfus and Dreyfus (2005). For her, admitting that our expertise, and indeed all agency, derives from nonhuman ingredients is not only an ontological matter (Barad, 2003), or a form of progressive politics (Haraway, 1991), it can also be an ethical strategy. However, Bradiotti, like Barad and indeed Haraway, is far from clear on exactly how 'posthuman' human expertise is recognized as such; through what process do these assemblages of interactions between humans and nonhumans become durable and stable, that is, how do they become legitimately socially valued (Knapp, 1999; Larson, 1977) and/or deliver measurable outcomes (Ericcson and Lehman, 1996; Ericcson et al 2007). Arguably the thinker that has done the most to help us understand how expertise is produced in a consistently recognizable fashion within our posthuman condition, is the influential STS scholar and philosopher, Bruno Latour.

\section{Latour's (1987) Metrologies}

In this final section, I will turn towards the work of one of the celebrated, and indeed controversial, social scientists and philosophers of recent decades - Bruno Latour. The work of Latour is perhaps the most well-known version of what I have termed here the 
'posthuman' condition, and his writing, unlike Haraway’s, Barad’s or Bradiotti’s, has already made a noticeable impact in construction management (e.g. Harty, 2008; Lingard et al. 2012; Trygesstad et al. 2010; Sage et al 2014). Despite not deploying the term 'posthuman' (Latour's preferred argument is that 'we have never been human' - see Latour, 1993), Latour's extensive writings all challenge the distinctly human ownership over agency and by extension expertise, none more so than his early work: Science in Action: How to Follow Scientists and Engineers Through Society. This text is one of 13 books single authored by Latour. To understand how Latour theorizes expertise within a posthuman condition I will address the closing passages of this book: his description of 'metrology' - the final process through which the concepts, practices, and technologies, indeed expertise, of scientists and engineers, and social scientists, comes to endure and be recognized as such.

In explaining this process through which scientific expertise is rendered knowable, and an aspect of reality appears as predictable, controllable, even detached, Latour (1987) makes a simply but powerful claim: 'The predictable character of technoscience is entirely dependent on its ability to spread networks further' (p250). Latour’s networks are chains of humans and nonhumans; in this sense they complement the relational ontologies given in Harways's (1991) cyborg figure, and Braidotti's (2013) posthuman and Barad's (2003) agential interactions; but Latour (1987) is far more explicit perhaps than these writers on the stabilizing dynamics of such interactions. As Latour (1987) explains, various techniques, mechanisms and actors are employed to ensure that the expertise of technoscience is rendered measurably constant. To enable this process certain networks must be put in place to provide consistent measures of scientific or engineering expertise. One example, which is pertinent to any construction project, is time. Latour's (1987) account of this process is worth quoting at length: 
If I ask, 'What time is it?', you will have to look at your watch. There is no way to settle this question without taking a reading at the window of this scientific instrument (the sun will do, but not when you need to catch a train [or construct a building!])..Time is not universal; every day it is made slightly more so by the extension of an international network that ties together, through visible and tangible linkages, each of all the reference clocks in the world and then organises secondary and tertiary chains of reference all the way to this rather imprecise watch I have on my wrist. There is a continuous trail of readings, checklists, paper forms, telephone lines, that tie all the clocks together. As soon as you leave this trail, you start to be uncertain about what time it is, and the only way to regain is certainty is to get in touch again with metrological chains (p251).

For Latour (1987) these metrological claims, these measuring devices, which are part human, part nonhuman, are integral to our agency, and especially our expertise, defined simply as an efficacy to accomplish a task, faster and better (Eyal, 2013). As he explains 'What we call "thinking with accuracy" in a situation of controversy is always bringing to the surface one of these forms. Without them we simply don't know' (Latour, 1987: 252). This process of networking building is intimately connected to the development of new forms of professional expertise, and the rise of a group of (human) experts attributed with expertise. And so, for example, for accountancy to become a valuable aspect of business expertise, a socially legitimate profession, with measurable performance outcomes, it is reliant upon the extension of number trails across the world, for example through the linking together of electronic cash registers, modern telecommunications, database, spreadsheets and barcodes (see Latour, 
1987: 254). Expertise in the profession of construction management is similarly reliant upon the extension of a networked infrastructure of metrologies that can measure this expertise and enable the attribution of this expertise to a group of experts. I have already discussed the significant example of time, but we could also add costs and quality to this 'iron triangle' of construction project management, and increasingly the evolving infrastructure of energy efficiency and carbon measures. Without the extension of these networks of measurement which are often largely dependent upon the work of nonhumans, it is difficult to imagine how we might recognize or think any construction management expertise as such. In this way, as Eyal (2013) suggests, Latour challenges much sociological writing on expertise in that the power of experts is not simply gained through monopolistic and autonomous processes (e.g. professional bodies, royal charters and the law) but also processes of extension, dialogue and collaboration. As Eyal (2013), via Latour, explains:

a network of expertise ... becomes more powerful and influential by virtue of its capacity to craft and package its concepts, its discourse, its modes of seeing, doing, and judging, so they can be grafted onto what others are doing, thus linking them to the network and eliciting their cooperation (p876).

Latour (1987) differs from Haraway and Brandiotti, in that his contribution to an analysis of expertise offers a less political and ethical emphasis, yet he shares their interest in understanding what might be termed our posthuman condition. In a sense Latour (1987) is closer to Barad (2003), and indeed the latter does cite the former as an influence. With both Barad and Latour, expertise appears the result of emergent relations, yet for Barad these assemblages always seem to precede the emergence of bounded entities such as 'human 
expertise', while for Latour some entities can already have taken shape through prior work, in his terms they are already 'black boxed', and can be deployed to sustain still other networks.

\section{Concluding comments: towards a posthuman theory of construction expertise}

The four theorists discussed here offer only a very modest indication of the depth and breadth of thinking around posthumanism (see Herbrecheter, 2013; Roden, 2015). And moreover, the term 'posthuman' does not itself encompass every contribution to the critique of humancentred social science. Moreover, both Latour and Haraway would no doubt reject the label 'posthuman' (Haraway, 2008; Latour, 1993). Indeed, across the social sciences, the 'posthuman turn', interweaves with other interdisciplinary turns such as 'the affective turn' (Halley and Clough, 2007), 'the materialist turn' (Kirsch, 2013) and the 'nonhuman turn' (Grusin, 2015a). What unities these bodies of work is their concern in registering diverse intellectual currents that all challenge the humanistic and anthropocentric scaffolding of much social science thinking. The conceptual implication of these turns away from the selfgoverning human being, as the modus operandi of social science, are diverse. All these approaches challenge the human-orientation of key social science concepts such as agency, power, identity, subjectivity, ethics, discourse, knowledge and society (Braidotti, 2013; Herbrecheter, 2013; Roden, 2015). In this short paper I have fleshed out some indicative contributions that these posthuman approaches can make to the ways in which construction expertise is conceptualized and researched. By way of conclusion I will specify four avenues for further research along this direction, each drawing upon the four posthuman theorists discussed above; these being; (i) political boundary-making; (ii) local materializations; (iii) ethical experimentations; and (iv) infrastructural stabilizations. 
The notion of political boundary-making can be derived from the cyborg figure of Haraway (1991). For Haraway (1991) the distinction between human and nonhuman is a political act that always involves questions of power. Haraway's (1991) analysis is particularly germane when applied to the context of construction expertise and the question of project agency. Future research within construction management might seek to understand how different boundaries between humans and nonhumans appear within different projects at different times for political reasons. For example, within a project that is performing to expectations, that is, seemingly well-planned and under control, the ability to undertake a task faster and better might be easily attributed to humans, so that people are invested with agency over nonhumans (such as technologies, materials, soil and plant equipment). But what happens when a project is running late or is over-budget? In these scenarios these same boundaries, and accompanying humanistic notions of expertise, might be harder to sustain and humans will start to invoke all manner of nonhuman agencies, from inadequate materials to commodity markets, to poor soils, to actively diminish, or mediate, their own contribution to project agency. When a project is struggling, nonhumans often appear on the scene to make a difference to human agency, but here, the capacity of the human expert to accomplish a task with expertise, that is, faster and better, is already in doubt. These unexpected designations of nonhuman agency are far from trivial; they suggests how it is only under certain stable conditions (Latour, 2005) that humans can ignore what Cooren et al (2006) terms 'this human and non-human dance of agencies”' (p539). The interesting question is why, how, when, and where, are these different attributions of nonhuman agency drawn and what designations of construction expertise are constructed around them, and then what are their political effects and consequences of such boundary-making on the direction of construction projects and those working within and around them? 
Barad (2003) discusses the importance of localized materializations of matter and meaning within her concept of posthuman performativity. This process orientated concept suggests that expertise is created through localized interactions of measurement, rather than acts of measurement being the product of certain groups of expert people and their measuring tools. In the context of construction Barad's (2003) philosophy challenges the idea that experts are easily identifiable in advance of a given project or construction activity, instead their expertise to accomplish a task with more efficacy only becomes materialized and meaningful because of certain acts of measurement. In the body of this paper I discussed the example of surveyor whose expertise is enacted through her relations with her measuring apparatus and a field site. Future research in construction working with this notion could investigate through how different measurement processes enable and/or constrain the materialization of different types of expertise? Studies might, for instance, investigate how new processes of measurements, such as a project budgeting tool that incorporates carbon measurement as well as time and cost, might influence the production of new legitimatizations of professional expertise within a construction project.

Braidiotti (2013) suggests that in our relations with new technologies we can and do conduct ethical experiments through which we can remake ourselves, inventing new forms of subjectivity, ethics and community. In the context of construction, research which follows Braidiotti’s (2013) work might examine how the emergence of new technologies such as BIM modelling offer opportunities for people to rework their sense of who they, creating new professional communities, and modes of relating together ethically; in other words enacting new forms of expertise and expert communities. In the discussion above I suggested the 
example of a BIM hacker as a new expert - someone with clandestine involvement in the development of a BIM model; this person might be able to act with efficacy to shape the design and construction of a building for good or ill against the wishes of its designers, clients and users. With the increasing sophistication of hacking and the rise of cloud-based BIM, the ethical significance of this possibility might be far from remote (see e.g. Gunshon and Sherratt, 2014) and deserves further critical scrutiny.

My final future direction for research concerns the infrastructural stabilizations required for expertise to be recognized as such, and attributed to human actors. This avenue of work stems from the work of Latour (1987), and is associated principally with Actor-Network Theory (Latour, 2005). Latour (1987) suggests that all expertise is infrastructural - it does not exist sui generis in the minds or bodies of people, rather it requires an infrastructure of standards through which it can be measured and rendered meaningful. But importantly, these standards are not simply determined by professional bodies and peers (such as RIBA, CIOB etc.) as suggested by much sociological writing on expertise (Evetts, 2006; Friedson, 2001; Knapp, 1999; Larson, 1977), they are also mediated through a networked array of nonhuman actors such as documents, bureaucracies, and other standardizing technologies through which expertise can be consistently measured. And importantly, as Latour (1987) explains, the larger this network is, the more powerful a particular strand of expertise becomes (see Eyal, 2013). Moreover, as this network of standardization expands, and is taken-for-granted, it disappears from view so that it 'makes it appear as if expertise is embodied 'by the expert'” (Eyal, 2013: 871). Within construction, future research along this vein of thinking could address crises and innovations in the infrastructural stabilizations along which building expertise must travel. These crises could be differences in construction standards when teams work on international projects, or issues around technical interoperability and compatibility; 
such crises shed light on the importance of specific pieces of infrastructure in the extension of expertise. Similarly, work addressing innovations and infrastructural stabilizations could seek to understand the work required to enable new forms of expertise to travel, for example along which networks, through which human and nonhuman mediators, do new forms of project management expertise, such as those mandated by the PMI (Project Management Institute), travel.

While the directions for future research mapped out here remain indicative and not comprehensive, speculative not substantive, they do demonstrate how posthumanism can fuel novel agendas to forward the intellectual, political and ethical development of research around construction expertise. These four avenues for future research all think with posthumanism to challenge the human-centred ways in which construction expertise is commonly understood, whether influenced by sociology, psychology or computer science. Importantly, unlike proponents of expert systems in construction (Alkass et al. 1996; Okoroh and Torrance, 1999), none of these thinkers encourage us to make bold claims about the possibility of substituting human expertise with technical systems. What is more, these forays into posthumanism also complement the empirical accounts of recent sociological studies of construction professionals, and their social interactions, which all suggest how nonhuman agencies make a difference to expertise (Boureau, 2013; Dossick and Neff, 2011; Gluch and Räisänen, 2009). All of the thinkers mapped out here help us challenge the aggrandized view of human agency that accompanies most understandings of expertise. But, as Cooren et al (2006) explain, 'Speaking about non-human agency does not mean that objects become completely autonomous and that humans are reduced to puppets' (p537). Instead, we have proposed a more modest version of agency as simply making a difference to the flow of action; and moreover, as Latour (2005) explains, the human/nonhuman dance of agencies 
involves many moves 'between full causality and sheer inexistence...things might authorize, allow, afford, encourage, permit, suggest, influence, block, render possible, forbid and so on’ (p72). Thus, while I am sympathetic to the claims of Dreyfus and Dreyfus (2005) about the impossibility of machines replacing human expertise, I am also sceptical about the idea that humans ever act with recognizable and meaningful efficacy to accomplish a task if technologies, and other nonhumans, are simply regarded as passive tools for human ends. Indeed the unfeasibility of systems such as BIM to deliver expertise in problem-solving capabilities (Dossick and Neff, 2011), says as much about the ‘designed in’ aggrandization of abstracted human agency that frames the development of such systems as it does the prevalence of technological determinism. By starting from a conception of expertise that registers our posthuman condition, I have instead sought to clear a path between the scylla of anthropocentrism and the charydbis of technological determinism. I will end with an illustration from Latour (2005) that again helps explain again how this posthuman condition can figure in our understandings of construction expertise:

It's true that the force exerted by a brick unto another bricks, the spin of a wheel onto an axis, the balance of a lever onto a mass, the gearing down of a force through a pulley, the effect of fire on phosphorous, all of those of action seem to pertain to categories so obviously different from the one exerted by a 'stop' sign on a cyclist or that of a crowd over an individual mind that it seems perfectly reasonable to put material and social entities on two different shelves. Reasonable but absurd, one you realize that any human course of action might weave together in a matter of minutes, for instance, a shouted order to lay a brick, the chemical connection of cement and water, the force of a pulley upon a rope with a movement of the hand, the strike of a match to light a cigarette offered by a co-worker, etc. Here, the apparently reasonable 
division between material and social becomes just what is obfuscating any enquiry on how a collective action is possible. Provided of course that by collective we don't mean an action carried over by homogeneous social forces, but, on the contrary, an action that collects different types of forces woven together because they are different (p75; original emphasis).

\section{References}

Alder, H. Beat, M. Marx, C. Tamborrini, G. Langenegger, T. Bruehlmann, P. Steurer, J. and Wildi, L. (2014) Computer-Based Diagnostic Expert Systems in Rheumatology: Where Do We Stand in 2014?, International Journal of Rheumatology, DOI: http://dx.doi.org/10.1155/2014/672714

Alkass, S. Mazerolle, M. and Harris, F. (1996) Construction delay analysis techniques, Construction Management and Economics, 14, 375-394.

Barad, K. (2003) Posthumanist Performativity: Toward an Understanding of How Matter Comes to Matter, Signs: Journal of Women in Culture and Society, 28(3) 801-831.

Bennett, J. (2010) Vibrant Matter: a political ecology of things, Duke University Press, Durham.

Braidiotti, R. (2013) The Posthuman, Polity Press, Cambridge. 
Clough, P and Halley, J. (eds) The Affective Turn: Theorizing the Social, Duke University Press, Durham, NC.

Chan, A. Yung, E. Lam, P. Tam, C. and Cheung, S. (2001) Application of Delphi method in selection of procurement systems for construction projects, Construction Management and Economics, 19: 699-718,

Cooren, F. Thompson, F. Canestraro, D and Bodor, T. (2006) From agency to structure: Analysis of an episode in a facilitation process, Human Relations, 59(4): 533-565.

Dossick, C. and Neff, G. (2011) Messy talk and clean technology: communication, problem solving and collaboration using Building Information Modelling, Engineering Project Organization Journal, 1(2): 83-93

Dreyfus, H and Dreyfus, S. (2005) Expertise in Real World Contexts, Organization Studies, 26(5),779-792.

Ericcson, K. Krampe, R. and Tesch-Romer, C. (1993) The Role of Deliberate Practice in the Acquisition of Expert Performance, Psychological Review, 100(3), 363-406. 
Ericcson, K. And Lehman, A. (1996) Expert and exceptional Performance: Evidence of Maximal Adaptation To Task Constraints, Ann. Review Of Psychology, 47, 273-305.

Ericcson, K. Prietula, M. and Cokely, E. (2007) The Making of an Expert, Harvard Business Review, Jul-Aug, 85(7-8), 114-21

Evetts, J. (2006) Short Note: The Sociology of Professional Groups, Current Sociology, 54(1): 133-143.

Eyal, G. (2013) For a Sociology of Expertise: The Social Origins of the Autism Epidemic, American Journal of Sociology, 118(4), 863-907.

Feigenbaum, E. (1992) A Personal View of Expert Systems: Looking Back and Looking Ahead, Report No. KSL 92-41, Knowledge Systems Laboratory, Stanford University, Stanford, CA, https://goo.gl/Nk5Xgc (accessed 28th August 2015)

Friedson, E. (2001) Professionalism: The Third Logic, Polity Press, Cambridge.

Gluch, P. and Räisänen, C. (2009) Interactional perspective on environmental communication in construction projects, Building Research \& Information, 37(2): 164-175

Grusin, R. (ed.) (2015a) The Nonhuman Turn, University of Minnesota Press: Minneapolis, MN. 
Grusin, R. (ed.) (2015b) Introduction, in Grusin, R. (ed) (2015a) The Nonhuman Turn, University of Minnesota Press: Minneapolis, MN, pp. vii-xxix.

Gunshon, K and Sherratt, F. (2014) Is BIM a security threat to the built environment, Construction Manager, http://goo.gl/4JyQ4C (accessed 29 ${ }^{\text {th }}$ August 2015).

Haraway, D. (1991) A Cyborg Manifesto: Science, Technology, and Socialist-Feminism in the Late Twentieth Century in Haraway, D. (ed) Simians, Cyborgs and Women: The Reinvention of Nature, Routledge, New York, pp. 149-181.

Haraway, D. (2008) When Species Meet, University of Minnesota Press: Minneapolis.

Harty, C. (2008) Implementing innovation in construction: Contexts, relative boundedness and actor-network theory, Construction Management and Economics, 26,1029-1041.

Herbrechter, S. (2013) Posthumanism: A Critical Analysis, Bloomsbury: London.

Kirsch, S. (2012) Cultural geography I: Materialist turns, Progress in Human Geography, 37(3), 433-441.

Knapp, S. (1999) Analyzing Narratives of Expertise: Toward The Development of a Burkeian Pentadic Scheme, The Sociological Quarterly, 40(4), 587-612. 
Larson, M. (1977) The Rise of Professionalism: A Sociological Analysis, University of California Press: Berkeley.

Latour, B. (1987) Science in Action: How to Follow Scientists and Engineers Through Society, Harvard University Press: Cambridge, Mass.

Latour, B. (1993) We Have Never Been Modern, Harvard University Press: Cambridge, Mass.

Latour, B. (2002) Morality and Technology: The End of Means, Theory, Culture \& Society, 19(5/6), 247-260.

Latour, B. (2005) Reassembling the social, Oxford University Press: Oxford.

Law, J. (2006) After Method: Mess in Social Science Research, Routledge: London.

Leigh, W. Modani, N. Purvis, R. and Roberts, T. (2002) Stock market trading rule discovery using technical charting heuristics, Expert Systems with Applications, 23, 155-159. 
Lingard, H. Cooke, T. and Blismas, N. (2012) Designing for construction workers’ occupational health and safety: a case study of socio-material complexity, Construction Management and Economics, 30(5), 367-382.

Okoroh, M. and Torrance, V. (1999) A model for subcontractor selection in construction projects, Construction Management and Economics, 17, 315-327.

Rae, G. (2014) The Philosophical Roots of Donna Haraway’s Cyborg Imagery: Descartes and Heidegger through Latour, Derrida, and Agamben, Human Studies, 37(4): 505-528

Reed, M (1996) Expert Power and Control in Late Modernity: An Empirical Review and Theoretical Synthesis, Organization Studies, 17(4), 573-597.

Roden, D. (2015) Posthuman life: philosophy at the edge of the human, Routledge: London.

Sage, D. Dainty, A. Trygesstad, K. Justesen, L. and Mouritsen, J. (2014) Building with wildlife: project geographies and cosmopolitics in infrastructure construction, Construction Management and Economics, 32, 773-786.

Shanteau, J. (1992) Competence in Experts: The Role Of Task Characteristics, Organizational Behaviour and Human Decision Processes, 53, 252-266. 
Styhre, A. (2011) In the circuit of credibility: construction workers and the norms of 'a good job’, Construction Management and Economics, 29, 199-209

Trygesstad, K. Georg, S. and Hernes, T. (2010) Constructing buildings and design ambitions, Construction Management and Economics, 28, 695-705.

Zald, M. and Lounsbury, M. (2010) The Wizards of Oz: Towards an Institutional Approach to Elites, Expertise and Command Posts, Organization Studies, 31(7), 963-996. 